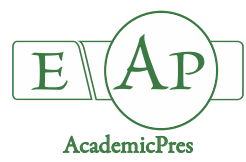

\title{
Adaptive Strategies of Structures that Enhance Invasion in Sicyos angulatus
}

\author{
Fengxi ZHAO ${ }^{1 a}$, Shihui YAN ${ }^{2 b}$, Meihui $\mathrm{LI}^{1}$, Xinyu LIU ${ }^{1}$, \\ Xinwan $\mathrm{ZHANG}^{1}$, Yong $\mathrm{CAO}^{1}$, Hong $\mathrm{ZHAO}^{1 *}$ \\ ${ }^{1}$ Shandong University, Weihai, Marine College, 180 Wenhua Xilu, Weihai, \\ China; zh_plant@163.com (*correspondingauthor) \\ ${ }^{2}$ Shandong Drug and Food Vocational College, Drug Research and Development Center, 1 Hexing Road, Weihai, China; yshyuru@163.com \\ ${ }^{a, b}$ These authors contributed equally to this work and should be considered co-first authors
}

\begin{abstract}
Sicyos angulatus may become an extremely dangerous invasive plant depending on its ability to naturalize and outcompete other species. To further understand the adaptive strategies of structures that could enhance its competitiveness, field surveys and experimental studies were conducted in plant communities where invasion may occur. The results showed that multistage branches of tendrils ensured that the plants could climb higher to strive for better photosynthetic opportunities. The single fleshy fruit of the infructescence was carpeted with slender white spines on which dense barbs were arranged, which could defend fruits against herbivores and contributed to long-distance dispersal. There would be beaklike lignified thorn forming to continue spreading when most of the barbed spines fell off during the fruit season. Rootstock was found in this herbaceous vine, which could accumulate various storage substances during development and helped the plants spread in harsh conditions. Moreover, the discovery of ants as new pollinators enriched the pollination system of $S$. angulatus, which greatly enhanced pollination efficiency. Above all, we conclude that this species has diverse adaptive strategies and a strong invasive capacity. It is urgent to find some way to slow or even stop its invasion effectively.
\end{abstract}

Keywords: adaptive strategies; exotic species; fine structures; invasion biology; Sicyos angulatus L.

\section{Introduction}

With accelerating interconnections in global trade and rapid changes in climate and land cover, the introduction and escape of invasive species have caused serious social impacts and ecological effects, which have attracted the close attention of the whole world (Chaffin et al., 2016). There are exotic species in every corner of the world, and Antarctica, which is unfrequented, is no exception (Tavares and De Melo, 2004). Nonnative invasive species can significantly disrupt ecosystem structure and function by affecting ecological processes and community dynamics (Gandhi and Herms, 2010; Yurkonis et al., 2010), directly reducing the number of native species and causing great harm to agriculture, forestry, animal husbandry, and fisheries in communities that have been invaded. Environmental and economic costs caused by the invasion of alien species have been calculated at more than $\$ 138$ billion per year in the United States (Pimentel et al., 2000).
Biological invasions are considered to be the second leading contributor to the loss of biodiversity worldwide only after habitat fragmentation (Enserink, 1999).

Burcucumber (Sicyos angulatus L., Cucurbitaceae) is a summer annual herbaceous vine that is native to the eastern United States (Britton and Brown, 1913). This species is widely planted as fence decoration because of its rapid vining growth and greening effect. However, it may become an extremely invasive plant depending on its ability to naturalize and crowd out other species. Thus, Delaware, Indiana, and Kentucky in the United States have considered it a harmful weed and have taken steps to limit its spread (Webb and Johnston, 1981; Smeda and Weller, 2001). The species has also been found in Canada, Mexico and the Caribbean Islands. S. angulatus was introduced into Europe in the 19th century as an ornamental species (Hulina, 1996). After that, it soon escaped to many European countries, such as former Yugoslavia, Austria, the Czech Republic, Italy, Romania and Russia (European portion and Siberia), Sweden, Norway, France, the United Kingdom, Spain, Germany and Turkey (Vasilchenko, 1957; Prodan 
1324

and Nyarady, 1964; Tutin, 1968; Uffelen, 1983; Ouren, 1987; Clement et al., 1994; Terzioglu and Ansin, 1999; Larche, 2004; Tzonev, 2005). Some countries in Asia have also suffered a great deal from $S$. angulatus. For example, this aggressive weed was discovered in Japan in 1952 (Nagata, 1972). It can develop in cultivated and uncultivated fields (Esbenshade and Orzolek, 2001) and invade native plant stands. According to the surveys made in Japanese, $S$. angulatus leads to the fields decrease by $80 \%$ with a population of $15-20$ individuals per $10 \mathrm{~m}^{2}$ and by $90-98 \%$ with a population of 28-50 individuals per $10 \mathrm{~m}^{2}$ (Tzonev, 2005). The Environment Government of Japan has designated the weed as an invasive alien species (ISA) by the Invasive Alien Species Act since 2006 (EPPO, 2010). There have also been reports about this invasive species in parts of South Korea and India in Asia (Chang et al., 2015; Thakur, 2016). In China, Liu and Yang (1999) reported the discovery of $S$. angulatus and described it simply. Several years later, some reports appeared in several regions of China in which this kind of liana encroached native vegetation and spread rapidly (Wang et al., 2005; Che et al., 2013; Cao et al., 2014). Except for human introduction, the long-distance dispersal of $S$. angulatus may be attributed to animal dispersal (Marks, 1992). Seabirds are known to nest in habitats where Sicyos occurs (Marks, 1992). The small, single-seeded fruits of many species of Sicyos can be transported across bird migration routes by means of adhering to the plumage of birds via their retrorsely barbed spines (Sebastian et al., 2012). In addition, species of Sicyos often occur in disturbed habitats, especially the widespread species $S$. angulatus (Sebastian et al., 2012). This species can grow in a wide range of habitats such as coastal areas, lowland shrub lands or rainforests up to 2000 meters in elevation. There is a vast area of adaptation of $S$. angulatus throughout the world, so it is urgent to find some way to slow or even stop its invasion effectively.

A series of advances have been made in the study of plant morphological structures and their adaptability to the environment. For example, Micco and Aronne (2012) explored the structural characteristics and adaptive strategies of plant drought resistance and found that the combination of different morphological structures could help plants adapt to different degrees of drought stress. However, studies on the biological properties of $S$. angulatus mainly include taxonomic descriptions. Some studies, such as Qu et al. (2010), described the species in more detail with manual drawings, but few studies have focused on its indepth morphology and anatomy and how these characteristics are related to its adaptive strategies and intensify invasions.

The purpose of this study is to elaborate on the morphology and anatomy of $S$. angulatus by means of 1 ) morphological observations, 2) a fine-structure anatomy study, 3) paraffin sectioning and pollen observations with a scanning electron microscope, Based on the above we can analyze the adaptive strategies of some special structures and evaluate of the invasive ability of $S$. angulatus. We expected to contribute to preventing invasions and proposing control strategies for $S$. angulatus based on the adaptive strategies we discuss below. We expected to contribute to preventing invasions and proposing control strategies for $S$. angulatus based on the adaptive strategies we discuss below.

\section{Materials and Methods}

\section{Field site and surveys}

The field investigation was carried out in Linhai Park in Weihai, China $\left(37^{\circ} 28^{\prime} 44^{\prime \prime} \mathrm{N}, 121^{\circ} 57^{\prime} 48^{\prime \prime} \mathrm{E}\right)$, which has a warm temperate continental monsoon climate with four distinct seasons. The dominant species in the park is Japanese black pine (Pinus thunbergii Parl.). Here, the cultivated tree species has developed into artificial pure forests with brooks on the ground underneath. All of these features form a damp, shady environment in which the expanding ability of the shade tolerant plant $S$. angulatus is strong (Zhang et al., 2007). Here, we found S. angulatus, which had established populations. $S$. angulatus invaded the area adjacent to Weihai and caused considerable damage, such as Dalian (Zhang et al., 2007). We began to monitor communities that were invaded and the surrounding areas. We continuously observed the population of $S$. angulatus for two years, recording the life-history strategies of this species and taking photos of its habitat and structural characteristics.

\section{Experimental design}

Samples were collected in Linhai Park seasonally. Some of the samples were dissected directly when fresh, and others were stored in formalin-aceto-alcohol (FAA) for subsequent experiments.

\section{Fine-structure anatomy study}

The fine-structure anatomy study focused on the fine structures of the plant organs by dissecting them directly when fresh and taking high-definition photos with macrophotography. We paid attention to the structures on the surface of the plants, such as the kind of hairs, the number, size, arrangement and bloom order of the male and female inflorescences, the number and size of the staminate flowers and pistillate flowers and their longitudinal sections, the traits of the anthers, stigma and ovaries in single flowers, and the surface and anatomical structures of the fruits and seeds. To track the growth trajectory of this weed, we collected specimens at different stages in its life history and compared. Through this procedure, we aimed to detail the morphological structures along with photographs and analyse how these structures enhance their invasive ability during growth.

\section{Paraffin section technology study}

Paraffin section technology showed the organizational structures of various organs of the plants, such as epidermal cells, parenchyma, mechanical tissue, and other special cells that have critical functions, such as sclereids. We looked at the paraffin slices under a microscope and took multiple pictures. Then, we picked out photos of the rootstock, stem, and leaf blade and looked at partially enlarged images to examine specific structures. In this experiment, we tried to examine whether the internal structures could make a difference on adaptability of $S$. angulatus. 
Observation of pollen with a scanning electron microscope

Pollen morphology is of special value in the study of plant origins, evolution, classification and phylogeny. The appearance and application of scanning electron microscopy (SEM) have pushed the study of pollen morphology into a more precise stage. To analyze $S$. angulatus with a very comprehensive description, we observed pollen grains using scanning electron microscopy and described them by shape, outline, approximate size, number of sulcus, ornamentation of the sulcus membrane and exine.

\section{Results}

\section{Morphologicalstructures}

Based on the observations and experiments, we optimized the description with high-definition photos covering all aspects of $S$. angulatus (Fig. 1). Plants are scandent or creeping, reaching $5-10 \mathrm{~m}$ in length and sometimes longer (Fig. 1A). There is a thick rootstock underground that seems to favor the storage of nutrients (Fig. 1B). We dug out the root and rootstock of $S$. angulatus in winter and found it completely dried; thus, we determined that it is an annual herbaceous vine. The stems are angular and covered with white hispid (Fig. 1C). There are axillary tendrils with 3-5 branches (Fig. 1D). The branches start from $2-5 \mathrm{~cm}$ above the base of the tendril and then branch again based on the primary branches, even with a tertiary branch. The leaves are alternately arranged and palmately 3-5-lobed or divided (Fig. 1E). The leaves on both sides are pubescent, with margin denticulate. The flowers are monoecious arising from a pubescent peduncle (Fig. 1F, I). Staminate flowers are $6-10 \mathrm{~mm}$ in diameter and assembled in racemose or paniculate inflorescences (Fig. 1b). We found some ants with excessive amounts of pollen coating their bodies crawling on the male flowers, which may make ants important pollinators of $S$. angulatus (Fig. $1 \mathrm{G}, \mathrm{H})$. Longitudinal cuttings of the staminate flowers showed that there was a significant disk under the anthers that united completely (Fig. 1c). The pistillate flowers are smaller than the staminate flowers, being 4-6 mm across and forming on compact cymes (Fig. 1a). The longitudinal sections of the pistillate flower include an inferior unilocular ovary covered by long prickle hairs, in which contains an anatropous ovule (Fig. 1d, e). There is a single style with three stigmas that are often enlarged (Fig. 1g). The corollas of both sexes are white or yellow-green with green striations and are densely covered with glandular hairs (Fig. 1F, I). The sepals are much smaller than the petals. There are many fruits growing on each plant, with 8-10 fruits clustered together (Fig. 1J, K, O). Each single fleshy fruit is ovateoblong with a pointed apex and is carpeted with dense articulate hairs and slender white spines (Fig. 1L, M). Dense barbs are arranged on each spine (Fig. 1M). The spines are usually muricate and verrucose on the surface of the fruit (Fig. 1L, P). During maturation, the slender, white spines and their barbs fall off gradually, while the verrucose points originating from the epicarp become beaklike (Fig. 1N, O, $\mathrm{P}, \mathrm{Q})$. The mature fruits are indehiscent with one seed per fruit (Fig. 1R). The seeds are ovate-oblong or ovate, slightly flat and 6-8 $\mathrm{mm}$ in diameter.

\section{Organizational structures}

The histological images obtained by the paraffin section show the organizational structures of the rootstock, stem and leaf blade (Fig. 2).

When observing the organizational structures of the thick organ growing underground, we find that its arrangement of vascular bundles was more similar to that in the stem rather than the alternative arrangement in the root (Fig. 2A, D). Therefore, we believe that the thick organ is rootstock, which is usually used to store nutrients. The xylem and phloem on the picture are suspected to be secondary structures, which seems evidence of $S$. angulatus as perennials (Radford and Bell, 1968). The primary structure should disappear during the growth of the secondary structure. A large number of sclereids appear beneath the epidermis (Fig. 2a). The cytoplasm of most of the sclereids is disintegrated, and some protoplasts still remain alive.

Below the epidermis of the stem is the cortex, which consists of the collenchyma and parenchyma (Fig. 2B, E). The collenchyma is found in the outer cortex and occurs as a continuous layer (Fig. 2b). There are several layers of sclerenchymata that separate the vascular area from the cortex. Among them, the xylem is located between the exophytic phloem and the endogenous phloem; that is, the vascular bundle belongs to the bicollateral bundle. There is a cambium between the phloem and xylem. The vascular zone surrounds a cavity that is formed by the destruction of myeloid cells early in life.

The main structures of the foliar transverse sections include the epidermal cells, the parenchyma cells, palisade tissue, spongy tissue and a small amount of mechanical tissue (Fig. 2C). The epidermal cells are closely arranged, having a few stomata and epidermal hairs. Outside the epidermis is a thin layer of stratum corneum. There is only one layer of palisade tissue cells in the mesophyll tissue. In the spongy tissue adjacent to the palisade tissue, the cells are arranged very loosely.

\section{Pollen morphology}

The pollen grains of $S$. angulatus are spheroid and have a diameter up to $>200 \mu \mathrm{M}$ (Fig. 2F). The finely echinate exine is colporate with reticulate veins on the whole surface. There are eight to ten embolic sulci (Fig. 2c). Each sulcus is the same length, which is equal to half the circumference of the pollen grain, and the sulci membrane is smooth.

\section{Discussion}

\section{Morphology strategies}

Rootstock is an important storage organ of nutrients and is common in biennial or perennial herbaceous dicotyledonous plants. Although rootstocks in perennials are also common in Cucurbitaceae, $S$. angulatus may be annual herbaceous vine because we dug out the root and rootstock of $S$. angulatus in winter and found it completely dried up. Therefore, it is notable to find a thick rootstock in such a short-lived type of vegetation. Reports on the rootstock of $S$. angulatus are limited to the rootstock of cucumber (Zhang et al., 2006), and none specified the function of the swollen modified stem. We analogized the 
1326
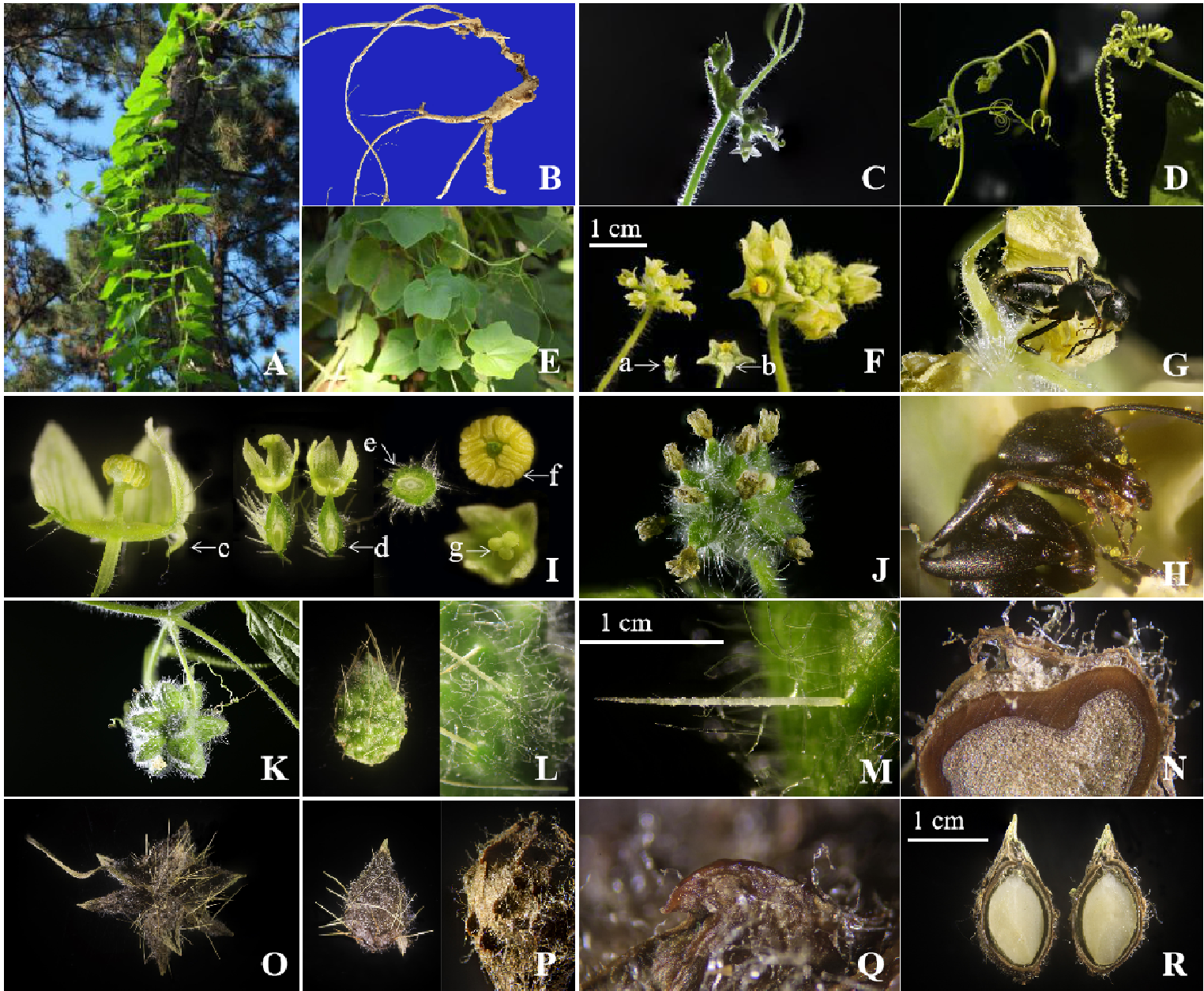

Fig. 1. The morphological structures of $S$. angulatus. (A) habitat. (B) rootstock and root. (C) stem. (D) tendrils. (E) leaf blade. (F) pistillate and staminate inflorescence and single flower. (a) pistillate flower. (b) staminate flower. (G, H) ants visiting staminate flowers. (I) anatomical structure of the flowers. (c) longitudinal sections of a staminate flower. (d) longitudinal sections of a pistillate flower. (e) transverse sections of $s$ pistillate flower. ( $\mathrm{f}$ ) anther. (g) stigmas. (J) fertilized pistillate flowers. (K) immature infructescence. (L) immature single fruit and its surface. $(\mathrm{M})$ spines. $(\mathrm{N})$ beaklike structure originating from the epicarp. (O) mature infructescence. (P) mature single fruit and its surface. (Q) beaklike structure. (R) seed.
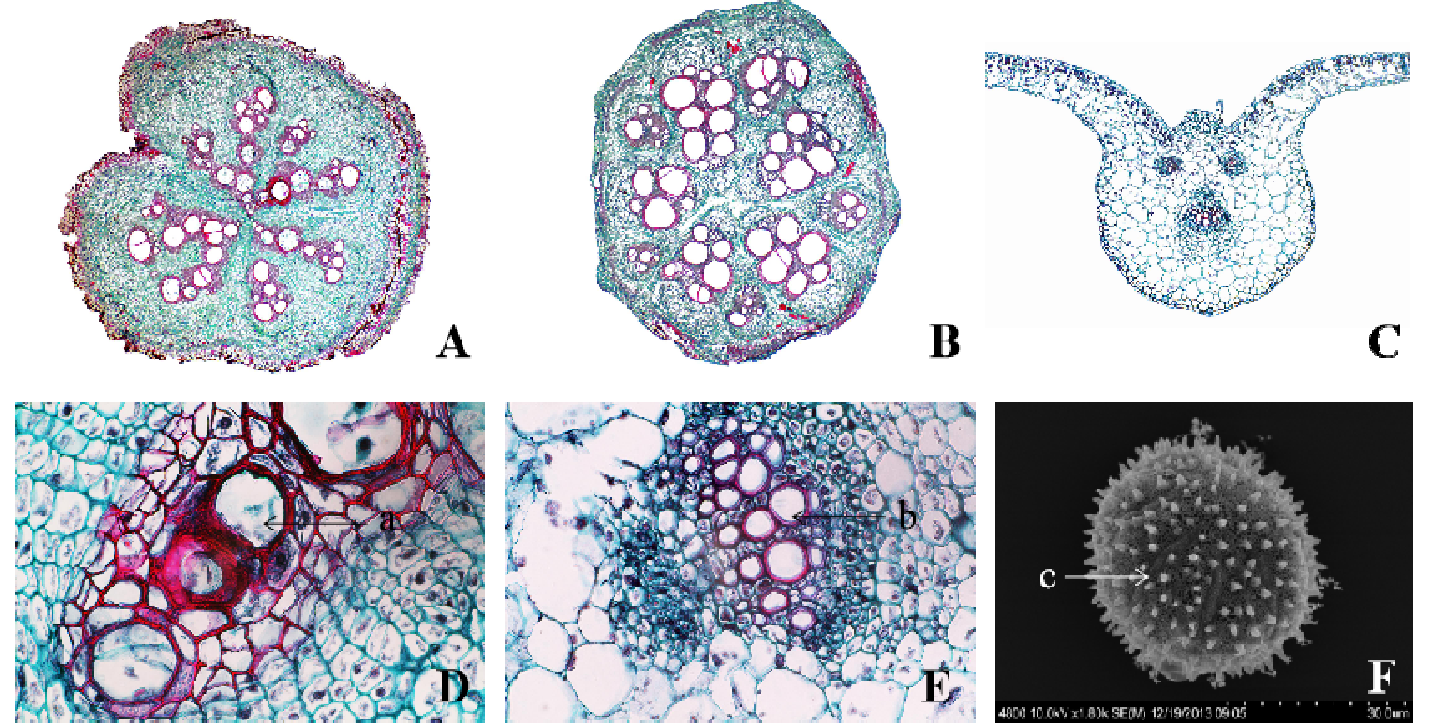

Fig. 2. The organizational structures of the leaf blade, stem and rootstock. (A) rootstock. (B) stem. (C) leaf blade. (D) partial enlarged detail of the rootstock. (a) sclereid in the rootstock. (E) partial enlarged detail of the stems. (b) collenchyma in a leaf. (F) pollen grain. (c) sulcus on a pollen grain 
organ to the conical aboveground tubers, the pachypodia, which often occur in perennial cucurbits. When rocky substrates make it difficult for underground water-storing root systems to form, pachypodia would bear an adaptive trait for surviving in xeric environments (Olson, 2003). We can infer that the developed rootstock should accumulate various storage substances during development and support the spread of the plant even in arid, saline and other harsh conditions.

Tendrils, the modified shoot common in Cucurbitaceae, are generally divided into simple tendrils, branched tendrils with a basal section that does not coil, and branched tendrils with a coiling basal section (Jeffrey, 1962, 1966; Lassnig, 1997). There are axillary tendrils bearing 3 to 5 branches in $S$. angulatus, which start from $2-5 \mathrm{~cm}$ above the base of the tendril. The plant will secure supports when the apex of the tendrils comes into contact with objects such as trees. If the tendrils and branches cannot reach the support, the primary branches will branch again. Similarly, tertiary branches may also occur if the plant cannot climb up the support with its primary and secondary branches. Once one of the branches suffers damage and cannot attach to support structures, the other branches would be an alternative. These multistage branches make the plant climb higher and strive for better photosynthesis opportunities.

The infructescence is composed of 8-10 ovate-oblong fruits. Each single fleshy fruit is carpeted with dense articulate hairs mixed with slender white spines with dense barbs arranged on each spine. The white articulate hairs simulating the spines are suspected as a warning. If animals ignore these hairs, the hard spines will stab the animals. Beyond that, Sebastian et al. (2012) believe that the particular spiny form of the fruits of Sicyos may be related to its spread. Therefore, we think that the dense barbs on the spines can attach to surrounding objects such as herbivores for long-distance propagation. However, the slender white spines with dense barbs will fall off gradually during maturation, while the verrucose points on the surface of the fruit originating from the epicarp will become beaklike. The beaklike structure may be another way to adhere to something that can catch the prickly fruit, such as the plumage or fur of animals. From this, we conclude that the major function of spines is a defense against herbivores. The secondary function of the spines is for the long-distance dispersal of $S$. angulatus, which may be mainly completed by the beaklike lignified thorn because most barbed spines will fall off during the period of fruit propagation. Species of Sicyos have very different types of fruits and have evolved astatically (Sebastian et al., 2012). Some are obovoid, fleshyfibrous and completely unarmed with an obtuse tip (Lira and Nee, 1999). Nevertheless, Sicyos species that have experienced long-distance dispersal events, such as $S$. angulatus, all have spiny fruits (Sebastian et al., 2012). The fruits of $S$. angulatus could even arrive thousands of kilometers away from their original habitat across birds migration routes (Carlquist, 1996).

\section{Anatomy strategies}

It was recorded that $S$. angulatus could reach more than $10 \mathrm{~m}$ in length. We even found the plant growing up to 20 $\mathrm{m}$ in follow-up investigations. Because the annual herb experiences highly seasonal growth with the underground organ drying completely in winter, the species lacks aboveground parts for long periods in the year (Gentry, 1991). From above, there must be some structures that support its rapid growth.

The structures of the leaf blades include a thin stratum corneum, a few stomata, only one layer of palisade tissue cells in the mesophyll tissue, and fewer mechanical tissues. All of these features validate that $S$. angulatus prefers humid, frequently irrigated and shady conditions. Although the potential for range expansion seems to be limited to arid, semiarid and relatively saline areas (Önen $e t$ al., 2018), $S$. angulatus can survive in many open and disturbed habitats along fencerows, wasteland, roadsides, and woodland borders (Zhang et al., 2007; Xu and Lu, 2017).

Several layers in the stem of the sclerenchymata that separate the vascular area from the cortex allow the vascular bundles to always be well protected, and transport efficiency may be thereby enhanced. Species of Cucurbitaceae are regarded as an excellent model for analyzing phloem function based on an integrated long-distance signaling network (Xoconostlecázares et al., 1999; Lough and Lucas, 2006). Except for photosynthate and some small molecules, there are a variety of macromolecules, such as proteins, that are found in the phloem translocation stream (Xoconostlecázares et al., 1999). These mechanical tissues and the components included in them have function in supporting the growth of long, nonwoody vines, which allows this species to climb and cover trees or shrubs. We found almost no other weeds surviving near $S$. angulatus, suggesting that this species is capable of rapid growth that allows it to outcompete neighboring species for sunlight and nutrients.

In addition, we found that a large number of sclereids appear beneath the epidermis of the rootstock. Most of the cytoplasm of these sclereids was disintegrated, leaving very thick lignified walls. It is the strongly lignified and thickwalled form that allows sclereids to have a mechanical function (Evert, 2006), which can protect the rootstock from the soil.

\section{Reproductive strategies}

The pollinators of $S$. angulatus that have been found are mainly bees, wasps, butterflies and various flies (Duchen and Renner, 2010). Other organisms have been observed visiting flowers in some Cucurbitaceae, which may also pollinate $S$. angulatus, such as bats (Duchen and Renner, 2010) and hummingbirds (Murawski and Gilbert, 1986). To our knowledge, no research has suggested ants as pollinators. The only connection between ants and cucurbits is fruit dispersal by harvesting ants (Renner et al., 2007). We have not found ants on the mature fruits of $S$. angulatus, and it seems impossible for ants to spread its fruits because the infructescence consists of 8-10 fruits, and each single fleshy fruit is carpeted with spines and a beaklike lignified thorn, which deters animals. However, we found some ants crawling on the male flowers during anthesis and picking up some pollen on their heads and mouthparts. This suggests ants could be pollinators of $S$. angulatus. Although the pollination mechanism by ants is not yet clear, the discovery of new pollinators shows that the pollination system of $S$. 
1328

angulatus may evolve specially with a change of habitat, which greatly enhances the pollination efficiency. The strong ability of pollination and the variety of pollination mechanisms of $S$. angulatus will inevitably lead to a higher fruit set rate, which will cause it to expand more quickly.

Except for the rootstock and root, there was no sign of growth of adventitious roots. Therefore, we speculate that the strong survival ability and high propagation rate of $S$. angulatus is mainly due to sexual reproduction. The flowers of most Cucurbitaceae are diclinous and monoecious, and dioecy seems to be the ancestral condition based on the family phylogeny (Schaefer and Renner, 2011). The diclinous flowers of $S$. angulatus are monoecious, and male and female flowers are self-incompatible. The staminate flowers are 6-10 $\mathrm{mm}$ in diameter, and the pistillate flowers are smaller, being 4-6 $\mathrm{mm}$ across but in much higher quantities. This increases the chance of the pistillate flowers being fertilized. The corollas of both sexes are white or yellow-green with green striations and are densely covered with glandular hairs. We think this former feature can also attract pollinators and the latter can facilitate insects walking on the perianth. A single style with three stigmas that are often enlarged to mimic an androecium attracts pollinators who have already visited the male flowers (Dukas, 1987; Rust et al., 2003). In the flowering period, the axils of the upper part of the stem are filled with male and female inflorescences. There are hundreds of fruits on each plant, with each fruit containing one compressed smooth seed. Analyzing the evolutionary tendency of fruits with molecular trees, multiseeded fruits have been inferred to be the ancestral condition, while one-seeded fruits, such as those in Sicyos, evolved secondarily (Kocyan et al., 2007). The single large seed is covered with a crustaceous pericarp (Britton and Brown, 1913), which is actually covered with various types of protective layers (Barber, 1909). These seeds will be well protected until they are detached from the plant. Then, there will be hundreds of plants next spring if every seed germinates successfully.

$S$. angulatus has been considered an invasive alien species by dozens of countries because its harmful invasion has caused undesirable economic and ecological impacts. The weed has a suite of ecologically advantageous traits, such as a strong reproductive ability by producing abundant fruits and a high propagation rate by climbing with branched tendrils or dispersing with animals. Moreover, S. angulatus can also grow in a wide range of habitats, and thus, it can rapidly invade after it arrives. We found a population of $S$. angulatus in Weihai and realized that this species has strong expansion ability. This study detailed the morphological structures of $S$. angulatus and discussed the adaptive strategies of invasion in $S$. angulatus. Based on the findings, we advise that effective preventive and control measures can be implemented as follows. First, the mechanical control of the early life stages should be considered. There are hundreds of fruits on each plant, which is attributed to ample inflorescences and kinds of pollinators during the flowering season. Thus, we should pull seedlings in spring and repeat this action many times to remove the seedlings as much as possible because $S$. angulatus has a strong resistance to herbicides (Messersmith et al., 1999; Esbenshade et al., 2001), and it is necessary to cut the stems near the rootstock or remove the fruits before the mature fruits are taken somewhere suitable for seed germination. Second, several studies have focused on developing the byproducts of $S$. angulatus (Zhang et al., 2006; Kim et al., 2016; Kim et al., 2017). One example is that effect of using burcucumber as rootstock on the fruit qualities of cucumber plants is better than that using black seed pumpkin as rootstock (Zhang $e t$ al., 2006). Its application provides novel insights into the governance of $S$. angulatus. Perhaps it will become a useful cash crop rather than a harmful weed. Finally, monitoring measures that include risk assessments and extensive surveys could be a low-cost and effective approach. Only continuous prevention, control, and follow up monitoring can effectively address biological invasions.

\section{Acknowledgements}

This work was supported by the Collection and Production of Wild Plant Specimens in Mountain Area of Eastern Shandong for Shandong Museum, grant number SHZB2018-201.

\section{Conflict of Interest}

The authors declare that there are no conflicts of interest related to this article.

\section{References}

Barber KG (1909). Comparative histology of fruits and seeds of certain species ofCucurbitaceae. Botanical Gazette 47(4):263-310.

Britton N, Brown A (1913). Scientific books: an illustrated flora of the Northern United States, Canada and the British possessions from Newfoundland to the Parallel of the Southern Boundary of Virginia, and from the Atlantic Ocean Westward to the $102 \mathrm{~d}$ Meridian. Science $4(6): 176-180$.

Cao ZL, ZhangJL, Wang YH, Zhang LH, DongJG, Song SP (2014). An invasive alien weed Sicyos angulatus L. causes great harm to corn. Plant Protection 40(2):187-188.

Carlquist $S$ (1996). Plant dispersal and the origin of Pacific island floras. In: Jeast A, Miller SE(Eds). The origin and evolution of Pacific island Biotas, New Guinea to eastern Polynesia: patterns and processes. Amsterdam: SPB Academic Publishingpp 153-164.

Chaffin BC, Garmestani AS, Angeler DG, Herrmann DL, Stow CA, Nyström M, ... Allen CR (2016). Biological invasions, ecological resilience and adaptive governance. Journal of Environmental Management 183(Pt2):399-407.

Chang WL, Kim D, Cho H, Lee H (2015). The Riparian vegetation disturbed by two invasive alien plants, Sicyos angulatus and Paspalum distichum var. indutum in South Korea. Ecology and Resilient Infrastructure 2(3):255-263.

Che JD, Jia FY, Liang TS (2013). First record of the invasive plant Sicyos angulatus in Beijing City. Weed Science 31(1):66-68.

Clement EJ, Foster MC, Kent DH (1994). Alien plants of the British Isles. Botanical Society of the British Isles London UK.

Duchen P, RennerSS (2010). The evolution of Cayaponia (Cucurbitaceae): 
repeated shifts from bat to bee pollination and long-distance dispersal to Africa 2-5 million years ago. American Journal of Botany 97(7):11291141.

Dukas $\mathrm{R}$ (1987). Foraging behavior of three bee species in a natural mimicry system: female flowers which mimic male flowers in Ecballium elaterium (Cucurbitaceae). Oecologia 74(2):256-263.

Enserink M (1999). Predicting invasions: biological invaders sweep in. Science 285:18341836.

EPPO (2010).EPPO data sheet on invasive alien plants: Fiches informatives sur les plants exotiques envahissantes Sicyos angulatus. EPPO Bulletin 40:401-406.

Esbenshade WR, Curran WS, Roth GW, Hartwig NL, Orzolek MD (2001). Effect of row spacing and herbicides on burcucumber (Sicyos angulatus) control in herbicide-resistant corn (Zea mays). Weed Technology 15(2):348-354.

Esbenshade WR, Orzolek MD (2001). Effect of tillage, row spacing, and herbicide on the emergence and control of burcucumber (Sicyos angulatus) in soybean (Glycinemax). Weed Technology 15(2):229-23.

Evert RF (2006). Esau's plant anatomy: meristems, cells, and tissues of the plant body: their structure, function, and development, third edition. Wiley-Interscience 60 (45):2128-2134.

Gandhi K, Herms D (2010). Direct and indirect effects of alien insect herbivores on ecological processes and interactions in forests of eastern North America. Biological Invasions 12(2):389-405.

Gentry AH (1991). The distribution and evolution of climbing plants. In: Putz FE, Mooney HA (Eds). The biology of vines. Cambridge University Press, Cambridge pp 3-42.

Hulina N (1996). New dangerous weed in croatia: Sicyos angulatus L. (Cucurbitaceae). PoljoprivrednaZnanstvenaSmotra61(3-4):259-264.

Jeffrey C (1962). Notes on Cucurbitaceae, including a proposed new classification of the family. Kew Bulletin 15(3):337-371.

Jeffrey C (1966). On the classification of the Cucurbitaceae. Kew Bulletin 20(3):417-426.

Kim JG, Kim MS, Hong SH, Kim JG (2016). The applicability of burcucumber (Sicyos angulatus L.) as a substitute for nitrogen fertilizer. Korean Journal of Environmental Agriculture 35(1):1-5.

Kim Y, Noh J, Hwang J, Kim K, Choi D, An J, ... Lee C (2017). Sicyos angulatus ameliorates atherosclerosis through downregulation of aortic inflammatory responses in apolipoprotein E-deficient mice. Experimental and Therapeutic Medicine 14(6):5863-5870.

Kocyan A, Zhang LB, Schaefer H, Renner SS (2007). A multi-locus chloroplast phylogeny for the Cucurbitaceae and its implications for character evolution and classification. Molecular Phylogenetics and Evolution 44(2):553-577.

LarchéJF (2004). Sicyos angulatus, a new weed for corn crops in SW France. Phytoma 571:19-22

Lassnig P (1997). Verzweigungsmuster und Rankenbau der Cucurbitaceae. Franz Steiner Verlag, Stuttgart.

Lira R, Nee M (1999). A new species of Sechium sect. frantzia (Cucurbitaceae, Sicyeae, Sicyinae) from Mexico. Brittonia 51(2):204 209.

Liu HY, Yang YB (1999). Taiwan vascular plant. Taipei: Council of
Agriculture, Executive Yuan 3:235.

Lough TJ, Lucas WJ (2006). Integrative plant biology: role of phloem longdistance macromolecular trafficking. Annual Review of Plant Biology 57(1):203-232.

Marks JS (1992). Breeding biology of Tristram's Storm-Petrel on Laysan Island. Wilson Bulletin 104(4):719-731.

Messersmith DT, Curran WS, Hartwig NL, Orzolek MD, Roth GW (1999). Evaluation of several herbicides for burcucumber (Sicyos angulatus) control in corn (Zea mays). Weed Technology 13(3):520524.

Micco VD, Aronne G (2012). Morpho-anatomical traits for plant adaptation to drought. In: Aroca $\mathrm{R}(\mathrm{Ed})$. Plant responses to drought stress. Springer VerlagBerlin pp 37-61.

Murawski DA, Gilbert LE (1986). Pollen flow in Psiguria warscewiczii: a comparison of Heliconius butterflies and hummingbirds. Oecologia 68(2):161-167.

Nagata (1972). Illustrated Japanese alien plants. Hokuryu-kan, Tokyo pp 50.

Olson ME (2003). Stem and leaf anatomy of the arborescent Cucurbitaceae Dendrosicyos socotrana, with comments on the evolution of pachycauls from lianas. Plant Systematics and Evolution 239(3-4):199-214.

Önen H, Farooq S, Tad S, Özaslan C, Gunal H, Chauhan BS (2018). The influence of environmental factors on germination of burcucumber (Sicyos angulatus L.) seeds: implications for range expansion and management. Weed Science 66(4):1-8.

Ouren T (1987). Soyabean adventitious weeds in Norway. Blyttia 45(4):175-185.

Pimentel D, Lach L, Zuniga R, Morrison D (2000). Environmental and economic costs of nonindigenous species in the United States. Bioscience 50(1):53-65.

PorterDM (1984). Endemism and evolution in terrestrial plants. In: Perry R (Ed).Keyenvironments. Pergamon Press, Galapagos pp 85-99.

Qu X, Baskin JM, Baskin CC (2010). Whole-seed development in Sicyos angulatus (Cucurbitaceae, Sicyeae) and a comparison with the development of water-impermeable seeds in five other families. Plant Species Biology 25(3):185-192.

Radford AE, Bell CR (1968). Manual of the vascular flora of the carolinas. Quarterly Review of Biology 20(22):377-378.

Renner SS, Schaefer H, Kocyan A (2007). Phylogenetics of Cucumis, (Cucurbitaceae): Cucumber (C. sativus) belongs in an Asian/Australian clade far from melon (C. melo). BMC Evolutionary Biology 7(1):58.

Rust RW, Vaissière BE, Westrich P (2003). Pollinator biodiversity and floral resource use in Ecballium elaterium (Cucurbitaceae), a Mediterranean endemic. Apidologie 29(34):29-42.

Schaefer H, Renner SS (2011). Cucurbitaceae. In: Kubitzki K(Ed). Families and Genera of Vascular Plants. Springer Verlag, Berlin pp 112-174.

Sebastian P, Schaefer H, Lira R, Telford IRH, Renner SS (2012). Radiation followinglong-distance dispersal: the contributions of time, opportunity and diaspore morphology in Sicyos, (Cucurbitaceae). Journal of Biogeography39(8):1427-1438.

Smeda RJ, Weller SC (2001). Biology and control of burcucumber. Weed Science 49(1):99-105.

Tavares M,De MeloG (2004). Discovery of the first known benthic invasive 
1330

species in the southern ocean: the north atlantic spider crab hyas araneus found in the antarctic peninsula. Antarctic Science 16(2):129-131.

Terzioglu S, Anşin R(1999). A contribution to exotic plants of turkey: Sicyos angulatus L. Turkish Journal of Agriculture and Forestry Sciences 23(3):359-362.

Thakur AK (2016). Sicyos angulatus L. (Cucurbitaceae): a new adventive species for the flora of India. Scientific Correspondence 111(5):789.

Tutin T (1968). Sicyos L. In: Tutin TG (Ed). Flora Europaea. Cambridge University Press, Cambridge pp 139.

Tzonev R (2005). Sicyos angulatus (cucurbitaceae): a new adventive species for the flora of Bulgaria. Phytologia Balcanica 11(1):67-68.

Uffelen JV (1983). Rootstocks for grafting cucumbers. Groenten and Fruit 38(45):3435.

Vasilchenko I (1957). Sicyos L. In: Shishkin B, Bobrov E(Eds). Flora USSR. Editio Academiae Scientiarum URSS, Mosqua-Leningrad, Russia pp 123-124.

Wang Q, Yan LI, Chen C (2005). Sicyos, a naturalized genus of Cucurbitaceae in mainland China. Acta Botanica Boreali-Occidentalia Sinica 25(6):1227-1229.
Webb F, Johnston G (1981). Control of burcucumber in corn and soybeans. In: Proceedings of annual meeting of The Northeastern Weed ScienceSociety. Northeastern Weed Science Society, Delaware.

Xoconostlecázares B, Xiang Y, Ruizmedrano R, Wang HL, Monzer J, Yoo BC, ... Lucas WJ (1999). Plant paralog to viral movement protein that potentiates transport of mrna into the phloem. Science 283(5398):94 98.

Xu WC, Lu XJ (2017). Harm and control of Sicyos angulatus. Xiandai Nongcun Keji 7:32-32.

Yurkonis KA, Meiners SJ, Wachholder BE (2010). Invasion impacts diversity through altered community dynamics. Journal of Ecology 93(6):1053-1061.

Zhang SM, Wang Q, Jiang XP, Luan SJ, Dong-LiangLI, Wang YS (2007). Futher study on exotic plant in Dalian (i) alien invasive plant-Sicyos angulatus $\mathrm{L}$. in Dalian: their damages and prevention strategies. Journal ofLiaoningNormal University 30(3):355-358.

Zhang SP, Gu XF, Wang Y (2006). Effect of bur cucumber (Sicyos angulatus L.) as rootstock on growth physiology and stress resistance of cucumber plants. ActaHorticulturae Sinica 33(6):1231-1236. 